\title{
NRK wt Allele
}

National Cancer Institute

\section{Source}

National Cancer Institute. NRK wt Allele. NCI Thesaurus. Code C88935.

Human NRK wild-type allele is located in the vicinity of Xq22.3 and is approximately 249 $\mathrm{kb}$ in length. This allele, which encodes Nik-related protein kinase protein, plays a role in the modulation of both protein phosphorylation and the JNK pathway. Mutation of the gene is associated with breast cancer. 